\title{
Parthenocarpy in Summer Squash
}

\author{
R.W. Robinson ${ }^{1}$ and Stephen Reiners ${ }^{2}$ \\ Department of Horticultural Sciences, New York State Agricultural Experiment \\ Station, Geneva, NY 14456-0462
}

Additional index words. Cucurbita pepo, fruit set, seedless fruit, row covers, pollination

\begin{abstract}
Summer squash (Cucurbita pepo L.) cultivars were compared for ability to set parthenocarpic fruit. Some cultivars set no parthenocarpic fruit and others varied in the amount of fruit set when not pollinated. The degree of parthenocarpy varied with season, but the relative ranking of cultivars for parthenocarpy was generally similar. Cultivars with the best parthenocarpic fruit set were of the dark green, zucchini type, but some cultivars of other fruit types also set parthenocarpic fruit. A summer squash cultivar was developed that combines a high rate of natural parthenocarpy with multiple disease resistance. Yield of summer squash plants grown under row covers that excluded pollinating insects was as much as $83 \%$ of that of insect-pollinated plants in the open.
\end{abstract}

Parthenocarpic fruit development has long been recognized as an important characteristic for greenhouse cucumbers (Cucumis sativus L.) (Sturtevant, 1890). European greenhouse cultivars were selected in the 19th century for high yield, often without realizing that the basis for this productivity was their ability to set parthenocarpic fruit when bees and other pollinating insects were absent. Most greenhouse cultivars of slicing cucumbers grown today can set parthenocarpic fruit, and parthenocarpic pickling cultivars are of major importance in Europe (Tatlioglu, 1992).

Parthenocarpy of squash has received less attention. Parthenocarpy can be induced in Cucurbita by growth regulators (Gustafson 1941; Mori, 1947; Takashima and Hatta, 1955) or pollen extracts (Gustafson, 1937), but this is not a commercial practice in the United States. The most practical means of increasing fruit set of squash when pollination is inadequate would be the use of cultivars with an innate ability to set parthenocarpic fruit. Parthenocarpy may enable squash to be grown in greenhouses and in the field out of season, when staminate flowers or pollinating insects may be absent. Populations of bees have been sharply reduced in many areas of the United States recently because of mite infestation (Buchman and Nabhan, 1996), and this has adversely affected pollination of cucurbits and other crops. In addition, the use of plastic tunnels or other row coverings for summer squash is increasing, but these exclude bees and must be removed early to allow for insect pollination (Wells and Loy, 1985). If pollina-

Received for publication 5 Jan. 1998. Accepted for publication 22 Oct. 1998. The cost of publishing this paper was defrayed in part by the payment of page charges. Under postal regulations, this paper therefore must be hereby marked advertisement solely to indicate this fact.

${ }^{1}$ Professor, to whom reprint requests should be addressed.

${ }^{2}$ Assistant Professor. tion were unnecessary, row covers could be left intact longer to improve growth and early yield of squash and reduce losses from insects and insect-transmitted viral diseases.

Squash cultivars differ in sex expression, and fruit set may be poor early in the season when prices are often highest because the low temperature and high light intensity promote female sex expression (Wien, 1997). Parthenocarpy could permit the use of highly female cultivars early in the season without concern for pollination.

Early studies indicated that parthenocarpy of Cucurbita pepo did not occur, or was manifested too late in the season to be of value for early production. Durham (1925) closed 301 pistillate flowers of Cucurbita pepo plants to prevent insect pollination, but none set fruit. Nitsch (1952) determined that 'Acorn' winter squash would produce parthenocarpic fruit, but only after producing many pistillate flowers that did not set fruit. 'Royal Acorn' did not set fruit in our tests, which were terminated before the parthenocarpic stage of development described by Nitsch (1952).

Early set of parthenocarpic fruit in zucchini ranged from $0 \%$ to $42 \%$, depending on variety (Nijs and Zanten, 1982). Rylski (1974a) found that 'Zucchini Elite' set more parthenocarpic fruit than 'Bushy White', and Nijs and Balder (1983) reported differences among cultivars ranging from $17 \%$ set for 'Elite' to $87 \%$ for 'DG 4'. Om and Hong (1989) reported that 'Zucchini' and 'Caserta' were among the best of the 64 cultivars they tested for fruit set in an insect-proof greenhouse.

Our preliminary research (Robinson, 1993) indicated that considerable differences existed among summer squash cultivars for parthenocarpic fruit development. The purpose of this research was to: 1) further evaluate cultivars and breeding lines of summer squash for parthenocarpy and determine if any disease-resistant cultivar had good parthenocarpic fruit set; 2) evaluate seasonal variation in parthenocarpy; 3 ) investigate any association between parthenocarpy and fruit type; and 4) determine if the ability to set fruit without pollination would be of practical value for summer squash grown under row covers.
Experiments were conducted for 4 years on a Lima silt loam (fine-loamy, mixed, mesic, Glossoboric Hapludalf) at Geneva, N.Y. Fourweek-old transplants were set in the field and spaced at $0.9 \mathrm{~m}$ in rows on $1.5-\mathrm{m}$ centers. Weeds were controlled using recommended herbicides, cultivation, and hand weeding, while insect and disease pressure was monitored and protective treatments applied when warranted (Becker, 1992).

Over $95 \%$ of the first pistillate flowers to develop were closed before anthesis by placing plastic-covered wire around the unopened petals to prevent insect pollination. Any open flowers were removed within $2 \mathrm{~d}$ of anthesis to prevent development of open-pollinated fruit. Fruit from closed flowers were harvested immature, at the marketable stage for summer squash. Data were taken on percent parthenocarpy, i.e., the proportion of flowers that developed into mature, marketable fruit. Fruit produced from closed pistillate flowers of additional plants were allowed to develop to maturity to determine if they were seedless.

In 1992, a total of 307 pistillate flowers of 33 cultivars and breeding lines of summer and winter squash were closed to exclude pollinating insects. Twenty-six of the same cultivars and lines were grown in 1993, and a total of 672 pistillate flowers were tested for parthenocarpic fruit set. The cultivars and lines were classified according to fruit shape, color, and usage (summer or winter squash) to determine if there was any relationship between parthenocarpy and fruit type.

Nine cultivars of summer squash that differed in parthenocarpic tendency in the 199293 trials were selected for further testing in 1994, as well as another cultivar, 'Zucchini Elite'. A total of 308 pistillate flowers were closed to determine if they would set fruit without pollination.

The same 10 commercial cultivars were grown under row covers in 1994. Floating spunbonded polypropylene row covers (20 g.m ${ }^{-2}$; Kimberly Farms, Roswell, Ga.) were suspended over the plants $10 \mathrm{~d}$ after transplanting and supported by wire hoops spaced over every other plant. The row covers excluded bees and other pollinating insects. The cultivars were also grown in the open to compare parthenocarpic fruit yield under row covers with insect pollinated fruit production. Fruit at the marketable stage were harvested every 3 to $4 \mathrm{~d}$ for 3 weeks.

In 1996, five summer squash cultivars resistant to zucchini yellow mosaic virus (ZYMV) were compared with three susceptible cultivars by closing a total of 314 pistillate flowers to exclude pollinators. Three sources of ZYMV resistance were included: the genetically engineered 'Freedom II' and 'Prelude II' cultivars; 'Tigress' and 'Jaguar', which have ZYMV resistance derived from Cucurbita moschata (Duch. ex Lam.) ex Poir.; and 'Whitaker', with ZYMV resistance from Cucurbita ecuadorensis Cutler and Whitaker.

All trials included three replications of six plants for each cultivar/treatment. A random- 
ized complete-block design was used for all experiments involving flower closure. The row cover study was a split-plot with cultivar as the main plot and row cover as the subplot. Plants in all trials were spaced at $0.9 \mathrm{~m}$ in-row with $1.5 \mathrm{~m}$ between rows. Data were tested for significance using analysis of variance and means compared using the protected least significant difference (LSD).

\section{Results}

Appearance of fruit from nonpollinated flowers was similar to that of fruit from pollinated flowers; there were no significant differences in fruit shape or defects that would affect marketability. Ovaries of $<1 \%$ of the closed flowers enlarged somewhat after anthesis but aborted before reaching marketable stage. Mature fruit produced from closed pistillate flowers of other plants were entirely seedless, confirming that they were parthenocarpic.

Cultivars varied for the ability to set fruit without pollination in 1992 and 1993 (Table 1). Two-thirds of the entries in the 1992 trial set parthenocarpic fruit. The cultivar with the most parthenocarpic fruit was 'Chefini Hybrid', with $82 \%$ fruit set. Fruit set was lower in 1993 (22\% vs. $9 \%$ across all varieties, $P=$ 0.14 ), but the ability of the different cultivars and lines to set parthenocarpic fruit was generally similar each year $(P=0.64)$. Eleven cultivars set parthenocarpic fruit both years, and seven did not set fruit either year. Several cultivars set parthenocarpic fruit in one year but not in another.

Mean fruit set was significantly higher in $1994(29 \%)$ than in 1993 (9\%) (Table 1), but a lack of cultivar $\times$ year interaction $(P=0.07)$ indicated that relative response among cultivars remained similar over the 3-year period. 'Peter Pan', 'Early Prolific Straight Neck', and 'Yellow Crookneck' set few parthenocarpic fruit in 1992 and 1993 and few or none in 1994, whether grown under row covers without pollination or in the open with pistillate flowers closed. 'Chefini Hybrid' produced many parthenocarpic fruit from closed pistillate flowers in 1992 and 1994.

Some commercially available summer squash cultivars can produce a crop when grown under row covers without pollination (Table 2). 'Chefini Hybrid', which produced more parthenocarpic fruit from closed pistillate flowers than any other cultivar tested in 2 of the 3 years, produced the greatest amount of fruit when grown under cover. The yield was reduced only $17 \%$ relative to that of plants grown without covers.

The results under row covers were similar to those for closed flowers. 'Black Magic', 'Zucchini Elite', 'Black Beauty', and 'Gold Strike' produced more than one-third as much fruit under cover as when insect-pollinated, and all set parthenocarpic fruit from closed pistillate flowers. 'Peter Pan' and 'Yellow Crookneck' produced no fruit under row covers and few to no parthenocarpic fruit from closed flowers.

Parthenocarpic fruit set was relatively low in 1996, averaging $9 \%$ for all cultivars. The
Table 1. Total number female flowers closed and mean of parthenocarpic fruit set of squash cultivars and lines, 1992-94.

\begin{tabular}{|c|c|c|c|c|c|c|c|}
\hline \multirow[b]{2}{*}{ Cultivar or line } & \multirow[b]{2}{*}{ Type $^{z}$} & \multicolumn{3}{|c|}{$\begin{array}{c}\text { Total no. } \\
\text { female flowers closed }\end{array}$} & \multicolumn{3}{|c|}{$\begin{array}{l}\text { Mean parthenocarpic } \\
\text { fruit set }(\% \pm \mathrm{SE})\end{array}$} \\
\hline & & 1992 & 1993 & 1994 & 1992 & 1993 & 1994 \\
\hline Chefini Hybrid & $\mathrm{Z}$ & 11 & 36 & 33 & $82 \pm 10$ & $19 \pm 3$ & $73 \pm 8$ \\
\hline Gold Strike & YSN & 8 & 33 & 50 & $75 \pm 10$ & 0 & $8 \pm 5$ \\
\hline Black Beauty & $\mathrm{Z}$ & 7 & 20 & 27 & $71 \pm 22$ & $75 \pm 3$ & $63 \pm 10$ \\
\hline Black Magic & $\mathrm{Z}$ & 9 & 27 & 29 & $67 \pm 12$ & $44 \pm 7$ & $23 \pm 12$ \\
\hline NY-82-138 & $\mathrm{Z}$ & 2 & --- & --- & $50 \pm 33$ & --- & --- \\
\hline NY-92-728 & $\mathrm{Z}$ & 7 & --- & --- & $43 \pm 6$ & --- & --- \\
\hline Green Magic & $\mathrm{Z}$ & 12 & 28 & --- & $42 \pm 5$ & $15 \pm 6$ & --- \\
\hline NY-82-141 & $\mathrm{Z}$ & 8 & --- & --- & $38 \pm 6$ & --- & --- \\
\hline Gold Slice & YSN & 6 & 28 & --- & $33 \pm 17$ & $4 \pm 3$ & --- \\
\hline Cocozelle & SSN & 7 & 27 & --- & $29 \pm 16$ & $15 \pm 4$ & --- \\
\hline Goldie Hybrid & YCN & 17 & 32 & --- & $29 \pm 5$ & $16 \pm 3$ & --- \\
\hline President & $\mathrm{Z}$ & 14 & 31 & --- & $29 \pm 15$ & $6 \pm 3$ & --- \\
\hline Black Jack & $\mathrm{Z}$ & 16 & 26 & 42 & $25 \pm 4$ & $23 \pm 2$ & $40 \pm 3$ \\
\hline Gold Rush & PYSN & 10 & 31 & --- & $20 \pm 10$ & $13 \pm 4$ & --- \\
\hline Caserta & SSN & 17 & 23 & --- & $18 \pm 2$ & $9 \pm 5$ & --- \\
\hline Golden Girl & YSN & 12 & 25 & --- & $17 \pm 8$ & 0 & --- \\
\hline Onyx & $\mathrm{Z}$ & 7 & 24 & --- & $14 \pm 8$ & $4 \pm 4$ & --- \\
\hline Senator & $\mathrm{Z}$ & 14 & 11 & --- & $14 \pm 7$ & 0 & --- \\
\hline NY-92-727 & $\mathrm{Z}$ & 14 & 18 & --- & $14 \pm 11$ & 0 & --- \\
\hline Hyrific & YSN & 9 & 32 & --- & $11 \pm 10$ & 0 & --- \\
\hline White Scallop & WS & 9 & 30 & --- & $11 \pm 5$ & 0 & --- \\
\hline Ambassador & $\mathrm{Z}$ & 10 & 25 & --- & $10 \pm 8$ & 0 & --- \\
\hline Yellow Crookneck & $\mathrm{YCN}$ & 8 & 21 & 46 & 0 & $10 \pm 7$ & 0 \\
\hline Gold Bar & YSN & 10 & 32 & --- & 0 & $6 \pm 3$ & --- \\
\hline Honey Boat & D & 4 & 18 & --- & 0 & 0 & --- \\
\hline Multi Pik & PYSN & 12 & 40 & --- & 0 & 0 & --- \\
\hline Peter Pan & GS & 11 & 25 & 26 & 0 & 0 & $4 \pm 4$ \\
\hline Royal Acorn & A & 5 & 15 & --- & 0 & 0 & --- \\
\hline Scallopini & GS & 9 & 25 & --- & 0 & 0 & --- \\
\hline Slendergold & YSN & 6 & 32 & --- & 0 & 0 & --- \\
\hline \multicolumn{8}{|l|}{ Early Prolific } \\
\hline Straightneck & YSN & 5 & 30 & 74 & 0 & 0 & $4 \pm 3$ \\
\hline \multicolumn{8}{|l|}{ Dark Green } \\
\hline Zucchini & $\mathrm{Z}$ & 5 & 5 & 26 & 0 & 0 & $39 \pm 23$ \\
\hline NY-92-730 & $\mathrm{Z}$ & 6 & 17 & --- & 0 & $6 \pm 6$ & --- \\
\hline Zucchini Elite & $\mathrm{Z}$ & --- & --- & 55 & --- & --- & $29 \pm 9$ \\
\hline $\operatorname{LSD}_{0.05}$ & & & & & 30 & 10 & 27 \\
\hline
\end{tabular}

${ }^{\mathrm{u}}$ Fruit type classifications:

A = Acorn. Round, ribbed dark green fruit. Winter squash.

$\mathrm{D}=$ Delicata. Cylindrical, cream-colored fruit with green stripes. Winter squash.

GS = Green scallop. Green, disc-shaped fruit with scalloped edges. Summer squash.

PYSN = Precocious yellow straightneck. Cylindrical becoming yellow. Summer squash .

SSN = Striped straightneck. Cylindrical fruit with dark green, longitudinal stripes. Summer squash.

YCN $=$ Yellow crookneck. Elongated yellow fruit with a crooked neck. Summer squash.

YSN = Elongated yellow fruit with a straight neck. Summer squash.

$\mathrm{WS}=$ White scallop. Light green when immature, later white disc-shaped fruit with scalloped edges. Summer squash.

$\mathrm{Z}=$ Zucchini type.

Table 2. Fruit yield of squash cultivars grown with and without row covers, 1994. Means and standard errors are presented.

\begin{tabular}{lccc}
\hline \hline Cultivar & $\begin{array}{c}\text { Without cover } \\
\left(\mathrm{t} \cdot \mathrm{ha}^{-1}\right)\end{array}$ & $\begin{array}{c}\text { With cover } \\
\left(\mathrm{t} \cdot \mathrm{ha}^{-1}\right)\end{array}$ & $\begin{array}{c}\text { Decrease in yield } \\
\text { with cover }(\%)\end{array}$ \\
\hline Chefini Hybrid & $16.3 \pm 2.1$ & $13.4 \pm 1.0$ & $17 \pm 5.4$ \\
Black Magic & $17.5 \pm 1.5$ & $9.7 \pm 1.1$ & $44 \pm 1.8$ \\
Zucchini Elite & $27.7 \pm 2.7$ & $10.4 \pm 1.7$ & $62 \pm 3.4$ \\
Black Beauty & $18.3 \pm 1.8$ & $6.7 \pm 0.6$ & $64 \pm 1.7$ \\
Gold Strike & $19.6 \pm 1.0$ & $6.7 \pm 0.6$ & $66 \pm 2.3$ \\
Black Jack & $25.6 \pm 1.1$ & $4.2 \pm 0.7$ & $83 \pm 2.6$ \\
Zucchini Dark Green & $15.2 \pm 1.4$ & $1.2 \pm 0.1$ & $92 \pm 0.2$ \\
Early Prolific Straightneck & $19.1 \pm 1.6$ & $1.2 \pm 0.1$ & $93 \pm 0.4$ \\
Peter Pan & $14.6 \pm 1.1$ & 0 & 100 \\
Yellow Crookneck & $15.9 \pm 1.4$ & 0 & 100 \\
LSD $_{0.05}$ & 4.8 & 2.3 & 7.2 \\
\hline
\end{tabular}


percent parthenocarpic fruit set was: 'Whitaker', 44\% $\pm 7.4 \%$; 'Tigress', $10 \% \pm$ $6.5 \%$; 'Jaguar', $10 \% \pm 3.4 \%$; 'Prelude II', $5 \%$ $\pm 5 \%$; 'Black Jack', $2 \% \pm 2 \%$; 'Freedom II', $2 \% \pm 2 \%$; 'Caserta', $0 \%$; and 'Early Prolific Straight Neck', $0 \%(P=0.0001$, LSD $=13 \%)$.

\section{Discussion}

Cultivars and lines were classified according to fruit type (Table 1) to determine if there was any relationship between fruit type and parthenocarpy. Of the 27 cultivars included in both the 1992 and 1993 trials, the overall percent parthenocarpic fruit set for those groups over the 2 years was zucchini, $27.0 \% \pm 3.1 \%$; striped straightneck, $17.8 \% \pm 4.7 \%$; yellow straightneck, $10.4 \% \pm 3.6 \%$; precocious yellow straightneck, $8.2 \% \pm 3.4 \%$; white scallop, $5.5 \% \pm 4.2 \%$; yellow crookneck, $5.0 \% \pm 3.7 \%$; green scallop, $0 \%$; and acorn, $0 \%(P=0.0007)$.

Cultivars with the best parthenocarpic fruit set, whether produced under row covers or from closed pistillate flowers, were of the dark green, zucchini type. Dutch researchers (Nijs and Zanten, 1982) also noted that summer squash lines with dark green fruit produced the most parthenocarpic fruit. Nevertheless, not all dark green, zucchini-type cultivars had good parthenocarpic fruit set in our tests; 'Ambassador' and 'Onyx' set relatively poorly. 'Ambassador' also set poorly when not pollinated in tests by Nijs and Zanten (1982).

Yellow straightneck-type cultivars ranked relatively low for parthenocarpic fruit set. The yellow-fruited 'Gold Strike' appeared to have good parthenocarpic fruit set in 1992, but this was based on only a small sample size, and set few or no parthenocarpic fruit when a larger number of flowers were tested in 1993 and 1994.

Most of the cultivars set more parthenocarpic fruit in 1992 than in 1993. The higher incidence of parthenocarpy in 1992 was probably due to the considerably lower temperatures prevailing in that season, as low temperature promotes parthenocarpic fruit set of squash (Globerson, 1971; Nijs and Balder, 1983; Rylski, 1974a, 1974b; Rylski and Aloni, 1990).

Some yellow-fruited summer squash hy- brids or inbreds have a zucchini-type genetic background, since the $B$ gene for precocious yellow fruit color was backcrossed into zucchini cultivars (Shifriss, 1980). Shifriss (1981) backcrossed $B$ into 'Fordhook Zucchini Improved' to produce 'Precocious Fordhook Zucchini', and this cultivar is the parent of 'Gold Rush' and other precocious yellow hybrids. 'Gold Rush' set parthenocarpic fruit in both our 1992 and 1993 trials.

The scallop-type cultivars Peter Pan, Scallopini, and Scallop all had poor parthenocarpic fruit set. In agreement with these results, Om and Hong (1989) found that 'Early White Bush Scallop' set few parthenocarpic fruit. The green, striped cultivars Caserta and Cocozelle set parthenocarpic fruit in both 1992 and 1993, and 'Caserta' was reported by Om and Hong (1989) to set parthenocarpic fruit in their tests. 'Whitaker' had good parthenocarpic fruit set in 1996. This cultivar is of complex origin, with many C. pepo breeding lines and three other species in its pedigree, and the source of its ability to set parthenocarpic fruit is uncertain.

Parthenocarpy can supplement insect pollination and improve fruit set of squash when conditions are unfavorable for pollination, but the germplasm we tested cannot be expected to produce normal yield by parthenocarpy alone. None of the cultivars or breeding lines tested set as many fruit by parthenocarpy as when insect-pollinated. The ability of some cultivars to set fruit without pollination is fortuitous because they were not selected for this characteristic. It should be possible to breed squash for parthenocarpy by selection.

\section{Literature Cited}

Becker, R.F. 1992. Pest management recommendations for commercial vegetable and potato production. Cornell Coop. Ext. Bul. 142RV.

Buchman, S.L. and G.P. Nabhan. 1996. The forgotten pollinators. Island Press, Washington, D.C.

Durham, G.B. 1925. Has parthenogenesis been confused with hermaphroditism in Cucurbita? Amer. Nat. 59:283-294.

Globerson, D. 1971. Effects of pollination on set and growth of summer squash (Cucumis pepo) in Israel. Expt. Agr. 7:183-188.
Gustafson, F.C. 1937. Parthenocarpy induced by pollen extracts. Amer. J . Bot. 24:102-107.

Gustafson, F.C. 1941. Probable causes for the difference in facility of producing parthenocarpic fruit in different plants. Proc. Amer. Soc. Hort. Sci. 35:479-481.

Mori, H. 1947. On parthenocarpy in Cucurbita moschata Duch. induced by growth promoting substances and their effectiveness for preventing fruit abscission. J. Hort. Assn. Japan 16:154-160.

Nijs, A.P.M. den and J. Balder. 1983. Growth of parthenocarpic and seed-bearing fruits of zucchini squash. Cucurbit Genet. Coop. Rpt. 6:84-85

Nijs, A.P.M. den and N.J.D. Veldhuyzen van Zanten. 1982. Parthenocarpic fruit set in glasshouse grown zucchini squash. Cucurbit Genet. Coop. Rpt. 5:44-45.

Nitsch, J.P., E.B. Kurtz Jr., J.L. Liverman, and F.W. Went. 1952. The development of sex expression in cucurbit flowers. Amer. J. Bot. 39:32-43.

Om, Y.H. and K.H. Hong. 1989. Evaluation of parthenocarpic fruit set in zucchini squash. Res. Rpt. Rural Dev. Adm. (Suweon) 31:30-33.

Robinson, R.W. 1993. Genetic parthenocarpy in Cucurbita pepo L. Cucurbit Genet. Coop. Rpt. 16:55-57.

Rylski, I. 1974a. Effects of season on parthenocarpic and fertilized summer squash (Cucumis pepo L.). Expt. Agr. 10:39-44.

Rylski, I. 1974b. Fruit set and development of several vegetable crops grown under low temperature conditions. Proc. Intl. Hort. Congr. 3:375385.

Rylski, I. and B. Aloni. 1990. Parthenocarpic fruit set and development in Cucurbitaceae and Solanaceae under protected cultivation in a mild winter climate. Acta Hort. 287:117-126.

Shifriss, O. 1980. On the emergence of B cultivars in squash. HortScience 23:238-239.

Shifriss, O. 1981. The derivatives of 'Fordhook Zucchini' and their breeding value. Cucurbit Genet. Coop. Rpt. 4:46.

Sturtevant, E.L. 1890. Seedless fruit. Mem. Torrey Bot. Club 1:141-181.

Takashima, S. and S. Hatta. 1955. Effect of phytohormones on parthenocarpy in cucurbits. J. Hort. Assn. Jpn. 24:59-61.

Tatlioglu, T. 1992. Cucumber Cucumis sativus L., p. 197-234. In: G. Kalloo and B.O. Bergh (eds.). Genetic improvement of vegetable crops. Pergamon Press, Oxford, U.K.

Wells, O.S. and J.B. Loy. 1985. Intensive vegetable production with row covers. HortScience 20:822-826.

Wien, H.C. 1997. The physiology of vegetable crops. CAB Intl., Wallingford, Oxon, U.K. 